\title{
PESAN TOLERANSI BERAGAMA DALAM LIRIK LAGU DUA RATUS DUA BELAS KARYA JASON RANTI (ANALISIS SEMIOTIKA ROLAND BARTHES)
}

\author{
Aldi Madagi \\ Universitas Islam Negeri Sultan Maulana Hasanudidin Banten \\ email: aldimadagi@gmail.com
}

Paper Accepted: 21 Juni 2020

Paper Reviewed: 22-29 Juni 2020

Paper Edited: 01-17 Juli 2020

Paper Approved: 28 Juli 2020

\begin{abstract}
ABSTRAK
Melihat besarnya kritisisme yang timbul dalam setiap sepak terjangnya Jason Ranti dalam menyikapi fenomena-fenomena yang ada di Indonesia, membuat penulis tertarik untuk meneliti salah satu lirik lagu Karya Jason Ranti yang berjudul "Dua Ratus Dua Belas" dan dikaitkan dengan pesan toleransi beragama yang tersirat dalam lirik lagu tersebut. Metodologi penelitian pesan toleransi beragama dalam lirik lagu "Dua Ratus Dua Belas" karya Jason Ranti ini menggunakan metode kualitatif. Menurut Bog dan Taylor penelitian kualitatif adalah salah satu prosedur penelitian yang menghasilkan data deskriptif berupa ucapan atau tulisan dan perilaku orang-orang yang diamati. Menurut Kenneth D. Balley penelitian deskriptif adalah salah satu penelitian yang bertujuan untuk memberikan gambaran tentang suatu fenomena secara detail (untuk menggambarkan apa yang terjadi). Adapun paradigma penelitian yang digunakan dalam penelitian ini merupakan penelitian kontruktivis. Teknik pengumpulan data membaginya dua unsur pengumpulan data, yaitu primer dan sekunder. Data primernya berupa lirik lagu "Dua Ratus Dua Belas" karya Jason Rianti. Sedangkan untuk sekunder yakni video klip, compac disc, jurnal, berita luring dan daring, interview. Untuk teknik analisis datanya didasarkan pada metode semiotika konotasi dan denotasi Roland Barthes yang menekankan produksi tanda dengan mengkaji proses pertukaran makna dari sebuah tanda yang diciptakan seorang dalam melakukan aktivitas komunikasi. Lagu Dua Ratus Dua Belas karya Jason Ranti lahir dari beberapa hal. Berdasarkan makna pesan toleransi beragama secara denotasi di dalam empat belas bait lagu tersebut, ada tujuh bait yang berkenaan dengan pesan toleransi beragama yaitu bait ke satu, tiga, lima, delapan, sembilan, sepuluh dan tiga belas. Dari ketujuh bait tersebut secara denotasi memberikan pesan bahwa kelompok beragama minoritas sering disudutkan oleh kelompok beragama mayoritas dan seolah-olah kata kafir adalah sumber masalah di negara Indonesia. Serta berdasarkan makna konotasi dalam lirik lagu tersebut setelah dianalisis bahwa ada tujuh bait yang mendominasi pesan toleransi beragama di dalamnya. Bait tersebut memaparkan bahwa kehidupan umat minoritas beragama sangatlah dipandang sebagai pembawa masalah pada polemik besar pada medio 20142019 di negara Indonesia, sehingga sikap intoleran lebih mendominasi ketimbang toleransi yang ada. Pada lagu Dua Ratus Dua Belas Karya Jason Ranti mitos di dalamnya yaitu suatu pesan yang menyatakan bahwa toleransi beragama adalah ajaran kebaikan yang perlu dimiliki oleh seluruh umat manusia yang memeluk agama. Sementara intoleransi tidak diperkenankan oleh seluruh pemeluk agama. Sikap toleransi harus tetap dijaga pengimplementasiannya sebagai upaya menjaga persatuan di atas keberagaman.
\end{abstract}

Kata Kunci: Jason Ranti, Toleransi, Lagu Dua Ratus Dua Belas 



\section{PENDAHULUAN}

Acap kali kita selalu mendengar kata toleransi dengan berbagai macam kontek kata di dalamnya mulai dari toleransi beragama, toleransi berbudaya, dan masih banyak lainnya. Sesungguhnya apa yang dimaksud dengan kata "toleransi"? Menurut kamus besar Bahasa Indonesia toleransi adalah (1) Batas ukur untuk penambahan atau pengurangan yang masih diperbolehkan; (2) penyimpangan yang masih dapat diterima dalam pengukuran kerja. Dalam percakapan sehari-hari, pengertian yang ada di KBBI itu tentu saja benar.

Demikian pula hal toleransi sering sekali digemakan dalam setiap permasalahanpermasalahan sosial, budaya dan lainnya, membuatnya sudah tidak terasa asing lagi bagi masyarakat Indonesia yang mempunyai semangat kekuatan toleransi besar disetiap tatanan kenegaraannya, mulai dari ideologi, semboyan, dan lainnya. Maka dari itu menurut penulis, Indonesia adalah salah satu negara yang mempunyai rekam jejak sangat panjang terkait pengimplementasian toleransi sendiri. Menurut penulis toleransi adalah salah satu bagian terpenting dalam tumbuh dan hidupnya negara Indonesia, serta toleransi juga mempunyai dampak besar dalam menstabilkan negara.

Fenomena terkikisnya toleransi masyarakat Indonesia. sebenarnya toleransi bisa didorong melalui media penyampaian pesan. Karena media adalah salah satu alat untuk menghubungkan suatu pihak dengan pihak yang lainnya. Alat untuk menghubungkan ini umumnya sebagai benda yang berwujud. Padahal sesuatu yang abstrak di antaranya seperti lagu pun bisa dikatakan media penyampaian pesan. Lagu menjadi sesuatu yang abstrak karena kenyataannya lagu tak bisa divisualisasikan, namun bisa didengar dan dirasakan. Cara kerja lagu sebagai penyampaian pesan sebenarnya merupakan hal yang biasa, jika dibandingkan dengan media penyampaian pesan lainnya. Menjadi hal yang luar biasa ketika pendengar bisa mendapatkan pesan dalam sebuah lagu tersebut.

Lagu erat kaitannya dengan bahasa komunikasi antar manusia. Hal ini dikarenakan bahwa proses mendengarkan lagu juga merupakan salah satu bentuk komunikasi efektif. Dalam komunikasi. Bahasa merupakan unsur utama dalam komunikasi, karena membangun pesan. Sedangkan dalam buku "Teori Komunikasi Individu Hingga Massa," menyatakan bahwa studi bahasa sangatlah dipengaruhi oleh semiotika dan se-baliknya. Karena itu penting bagi kita untuk mengetahui mengenai struktur bahasa karena struktur mempengaruhi pesan.

Melalui struktur bahasa yang timbul akan menjadikannya sebagai pesan. Pesan juga sebagai rujukan untuk mengetahui makna yang terkandung dalam bahasa, dikutip dari buku "Analisis Teks Media" karya Alex Sobur, menyatakan bahwa semua ahli komunikasi, seperti dikutip Jalaluddin Rakhmat (1966) sepakat bahwa makna adalah kata yang sangat subjektif, world don't mean, people mean. Sekiranya ada buku yang menyampaikan secara objektif, Orang akan menunjuk kamus. Karena sang penulis kamus tersebut hanya menghimpun makna yang ia temukan dalam pemakaian, Dalam percakapan atau dalam tulisan.

Maka dari itu penulis tertarik kepada salah satu musisi Indie yang kerap melontarkan katakata sarkas atau satirnya di setiap lirik lagu yang ia buat, Yaitu Jason Ranti, seorang musisi yang berkarir solo yang menyebarkan dan mendistribusikan lagu-lagunya secara mandiri tanpa melalui bantuan atau pun terikat dengan sebuah label. Saat mendengar lantunan lagu Jason Ranti, penulis kerap sekali mendapatkan potongan lirik yang kontroversial di kehidupan nyata. Terkait politik misalnya, ada beberapa nama tokoh politikus Indonesia di antaranya Fadli Zon dan Fahri Hamzah. Mengenai isu sosial yang berkembang di antaranya ada penggalan bait yang membicarakan komunis, dan juga agama karena ada juga dalam potongan lirik lagu yang lainnya berbicara tentang kafir. Album perdana Jason Ranti dirilis pada tahun 2017 oleh label rekaman Demajors dan terdiri atas sebelas lagu yang popular antara lain "Variasi Pink, Bahaya Komunis dan Doa Sejuta Umat."

Melihat besarnya kritisisme yang timbul dalam setiap sepak terjangnya Jason Ranti dalam menyikapi fenomena-fenomena yang ada di Indonesia, membuat penulis tertarik untuk meneliti salah satu lirik lagu Karya Jason Ranti yang berjudul "Dua Ratus Dua Belas" dan dikaitkan dengan pesan toleransi beragama yang tersirat dalam lirik lagu tersebut.

\section{METODE PENELITIAN}

Metodologi penelitian pesan toleransi beragama dalam lirik lagu "Dua Ratus Dua Belas" karya Jason Ranti ini menggunakan metode kualitatif. Menurut Bog dan Taylor penelitian kualitatif adalah salah satu prosedur penelitian yang menghasilkan data deskriptif berupa ucapan atau tulisan dan perilaku orangorang yang diamati. 
Menurut Kenneth D. Balley penelitian deskriptif adalah salah satu penelitian yang bertujuan untuk memberikan gambaran tentang suatu fenomena secara detail (untuk menggambarkan apa yang terjadi). Adapun paradigma penelitian yang digunakan dalam penelitian ini merupakan penelitian kontruktivis. Menurut Little Jhon teori-teori kontruktivis berdasarkan pada ide bahwa realitas bukan bentukan yang objektif, tetapi diskontruksi melalui proses interaksi dalam kelompok, masyarakat, budaya.

Teknik pengumpulan data, penulis membaginya dua unsur pengumpulan data, yaitu primer dan sekunder. Data primernya berupa lirik lagu "Dua Ratus Dua Belas" karya Jason Rianti. Sedangkan untuk sekunder yakni video klip, compac disc, jurnal, berita luring dan daring, interview. Untuk teknik analisis datanya didasarkan pada metode semiotika konotasi dan denotasi Roland Barthes yang menekankan produksi tanda dengan mengkaji proses pertukaran makna dari sebuah tanda yang diciptakan seorang dalam melakukan aktivitas komunikasi.

\section{HASIL DAN PEMBAHASAN}

\section{Sosok Jason Ranti}

Jason Ranti atau yang akrab dipanggil Jeje adalah seorang pemusik Indonesia yang lahir pada 22 Oktober 1984. Namanya dikenal public setelah Jason Ranti merilis album pertama yang bertajuk "Akibat Pergaulan Blues" pada tahun 2017. Jason Ranti dianggap sebagai idola baru untuk pencinta musik indie dan folk. Sebelum terjun kedunia permusikan, ia pernah mengenyam pendidikan di Universitas Atma Jaya Jakarta, jurusan Ilmu Psikologi.Selain itu Ia juga pernah bekerja di sebuah bank dan masuk Program Pendidika Eksekutif (PPE). Namun tak lama berselang, ia memutuskan untuk keluar dan pindah bekerja ke sebuah Restoran Jepang menjadi kasir. Saat Jason Ranti bertemu dengan teman SMP yang kemudian menjadi istrinya yang bekerja sebagai dokter, Ia diberikan pekerjaan untuk mengajar les dari tingkat Sekolah Dasar hingga Sekolah Menengah Pertama.

Namun karir Jason Ranti di dunia musik dimulai dari bergabung dalam sebuah Band bernama Stairway to Zinna sebagai seorang gitaris. Bersama Stairway To Zinna, Jason Ranti pernah merilis Album bertajuk "Asisi" pada 2012 serta album kompilasi "Karol's Trip to Zinna" pada 2013 bersama Karon $n$ Roll, Tha's Rockefeller dan Indische Party. Jason Ranti yang sudah tertarik pada dunia permusikan sejak sekolah dasar pun memutuskan untuk bersolo karir. Keputusan untuk merilis album solo juga tidak lepas dari perjumpaannya dengan sosok yang menjadi produsernya sekarang, yaitu Junior Sumantri. Melalui Junior (akrabnya), Jason Ranti kemudian menggarap album "Akibat Pergaulan Blues." Selain itu ternyata Jason Ranti bertemu dengan Junior Sumantri di Earhouse milik musisi Endah N. Rhesa.

Sebagai musisi Jason Ranti memiliki satu tujuan sederhana yang menjadi alasan sekaligus kegelisahannya dalam bermusik. Ia hanya ingin hidupnya bisa bermanfaat untuk orang lain. Hingga akhirnya album "Akibat Pergaulan Blues" yang dikerjakan sejak akhir 2016 rilis pada 15 Mei 2017 dibawah naungan Demajors. Album ini berisi 11 lagu yang ditulis sendiri oleh Jason Ranti. Namun "Akbiat Pergaulan Blues" tercipta tanpa ada rencana yang jelas. Tak hanya itu, proses kreatif di balik pembuatan materi hingga artwork dikerjakan sendiri. Lagulagu secara keseluruhan juga merupakan proses natural dirinya sebagai musisi. Jason Ranti mengungkapkan inspirasi album tersebut juga tak terduga. Dikatakan inspirasi datang dari internet, di Warung Jamu, dari majalah Bobo dan terutama dari tokoh Rongrong dan Bona yang ada dalam majalah itu. Dua Tahun berselang pada Mei 2019, rumah produksi Sinema Pinggiran Merilis karya terbaru bertajuk "Sesudah Pergaulan Blues".

\section{Makna Denotasi dan Konotasi}

Lirik lagu Dua Ratus Dua Belas terdiri dari 14 bait di dalamnya. penulis akan menganalisis tujuh bait di dalam lirik lagu tersebut, karena ke-tujuh bait lagu tersebut memiliki pesan toleransi yang sangat berkaitan langsung di dalamnya, bait tersebut yaitu bait 1, 3, 5, 8, 9, 10 dan 13. Bait 1: Aku khawatir sebentar lagi anakku lahir, suhu dalam negeri tak kunjung stabil, kulihat tiada tanda-tanda penistaan akan berakhir, akal sehat diperkosa, hei penjahat apa rasanya.

Analisis denotasi menggambarkan kekhawatiran atau kecemasan seorang ayah karena keadaan atau situasi di suatu tanah tempat tinggalnya yang tidak pernah tenang, karena suatu hal yaitu: penistaan. Sehingga ia tidak bisa melihat bukti perbuatan menistakan atau mencela akan selesai. Selain itu perbuatan tersebut merusak pikiran yang baik dan normal dengan cara dipaksa melalui kekerasan oleh manusia yang dianggap jahat. Sementara 
analisis konotasinya menjelaskan perasaan khawatir atau cemas yang timbul dari diri seorang ayah lantaran keadaan, situasi dan kondisi di dalam suatu negara tidak berangsur membaik, dengan waktu yang cukup lama. Terlebih lagi penistaan dalam hal ini terkait dengan pencelaan terhadap kelompok manusia tertentu yang biasanya menunjuk pada kelompok minoritas agama. Diperkosa yang dimaksud dalam teks tersebut adalah pemaksaan terhadap pola pikir manusia agar seragam tetapi dalam hal yang tidak baik.

Bait 3: Kupergi ke kiri, ku pergi ke kanan. Kuingin mencari sekadar peace of mind. Barang sebentar, mungkin dua jam, dua hisapan. Kuingin mengintip masa depan, masa jalan. Ku rasa mencekam, kuucap takbir, Aku khawatir sebentar lagi anakku lahir.

Analisis denotasi dari kata $k u$ pergi menggambarkan seseorang yang berjalan atau bergerak; meninggalkan kiri dalam teks tersebut penggambaran arah, dalam bahasa politik dan pemerintahan kiri adalah sebutan kepada partai (golongan) berhaluan sosialisme yang lama menghendaki perubahan secara radikal (tentang politik, partai, dsb). Selanjutnya kanan dalam bahasa politik dan pemerintahan, kanan mengartikan partai atau golongan yang berhaluan moderat yaitu berdasarkan keagamaan, kebangsaan atau tradisi yang sudah ada di dalam percaturan politik dalam negeri sebagai lawan golongan kiri yang berhaluan keras dan berdasar pada sosialisme. Dalam kalimat selanjutnya kuingin mencari sekadar peace of mind kalimat kuingin mencari sekadar diartikan kehendak untuk berusaha mendapatkan sesuatu seperlunya yaitu peace of mind yang artinya ketenangan pikiran, dengan arti kata ketenangan pikiran. Dengan arti kata ketenangan pikiran yaitu suatu hal (keadaan) tenang, ketentuan (hati, batin, pikiran), pikiran adalah akal - ingatan. Dalam kalimat selanjutnya Barang sebentar, mungkin dua jam, dua hisapan menggambarkan kata barang adalah benda umum (segala sesuatu yang berwujud atau berjasad), sebentar yaitu dalam waktu yang singkat atau tidak lama, isap yang mengartikan hirup, dua hisapan adalah dua hirupan, dua jam mengartikan besaran waktu selama dua jam. Kalimat selanjutnya Kuingin mengintip masa depan, masa jalan. Mengintip pada kata tersebut berkorelasi dengan kata masa depan yang berarti mengamati dengan cemat dan diam-diam masa yang akan datang, sedangkan masa jalan adalah waktu, tempat untuk lalu lintas orang. Kurasa mencekam, kuиcap takbir, Aku khawatir sebentar lagi anakku lahir adalah kalimat terakhir dalam bait tersebut adalah kata kurasa yang mengartikan yang mengartikan ucap atau bagian kalimat yang dilisankan dengan seruan Allahu Akbar yang berarti Allah Maha Besar, selain itu dalam kalimat tersebut pengunkapan rasa kecemasan atau khawatir dengan situasi waktu dekat seorang manusia akan melahirkan keturunan.

Sementara analisis konotasi dalam bait beberapa kalimat menegaskan keresahan seorang Jason Ranti dalam menghadapi situasi dan kondisi tertentu. Baik dari peta gerakan politik nasional, agama dan ekonomi. Dalam peta politik Jason Ranti menjelaskan keinginannya dengan tegas dalam kalimat peace of mind, bahwa dirinya hanya ingin ketenangan berpikir bukan tentang pemikiran kiri atau kanan yang dapat mencondongkan pemikirannya. Tak berhenti disitu saja, dalam kalimat tersebut Jason Ranti juga menegaskan dalam kalimat barang sebentar, mungkin dua jam, dua hisapan. Makna konotasi dalam kalimat tersebut sangatlah berkorelasi dengan kalimat sebelumnya, yakni tentang keinginan Jason Ranti memiliki ketenangan berpikir. Dalam kalimat ini, Jason Ranti menegaskan untuk meminta waktu sebentar sedikitnya dua jam tetapi kalimat tersebut disandingkan dengan kata mungkin yang berarti belum tentu, yang bermakna jika dua jam terlalu banyak untuk menenangkan pikirannya, waktu selama dua isapan hembusan nafas itu lebih dari cukup untuk menenangkan pikirannya. Kalimat kuingin mengintip masa depan, masa jalan mempunyai makna konotasi dimulai dari kata kuingin yang bermakna suatu keinginan atau kehendak dan disandingkan dengan kata mengintip yang bermakna suatu pengamatan terhadap suatu objek tertentu yaitu masa depan atau masa yang akan datang. Kalimat masa jalan yang disandingkan dengan kalimat kurasa mencekam, kuucap takbir mengartikan unsur dalam perincian di mana terdapat tanda koma setelah kalimat selanjutnya, yang bermakna Jason Ranti sedang menghadapi situasi dan kondisi dan sangat amat mencemaskannya. Sehingga menurutnya kata takbir berubah pemaknaannya dan sangatlah membuatnya merasa cemas dengan situasi dan kondisi tersebut. Kalimat selanjutnya Aku khawatir sebentar lagi anakku lahir, mempunyai makna konotasi yang sangat erat kaitannya dengan kalimat sebelumnya, dimana seorang Jason Ranti yang sebentar lagi akan menjadi seorang ayah dan merasakan kecemasan atas situasi dan kondisi yang dilaluinya.

Bait 5: 30 persen dipotong teman, 20 persen untuk minuman. Yang tersisa kubawa pulang, Tapi kurasa ini masih kurang. Aku deg- 
degan jadi seniman, Aku khawatir sebentar lagi anakku lahir. Bait ini merupakan lanjutan dari bait sebelumnya. Makna denotasi dalam bait ini diambil beberapa kata, yaitu pada kalimat 30 persen dipotong teman, 20 persen untuk minuman, yang tersisa kubawa pulang, mempresentasikan penghasilan yang diperoleh selepas bekerja, dibagi beberapa di antaranya kepada teman 30 persen, konsumsi pribadi 20 persen dan sisa 50 persen untuk keluarga di rumah. Tapi kalimat kurasa ini masih kurang, dimaknai seorang manusia yang masih menyatakan ketidakcukupan dalam penghasilannya. Kalimat selanjutnya, aku degdegan jadi seniman, kata deg-degan tersebut berarti berdebar-debar atau bergerak-gerak, berdenyut lebih kencang dari pada biasanya (tentang jantung karena kaget dan sebagainya). Lalu kata seniman adalah orang yang memiliki bakat seni dan berhasil menciptakan dan menggelarkan karya seni. Kalimat terakhir dalam bait ini sudah ada pada bait sebelumnya, Aku khawatir sebentar lagi anakku lahir yang mengartikan bahwa berdebarnya hati seseorang menanti kelahiran seorang anak.

Makna konotasi baik kelima merupakan cerminan terkait faktor ekonomi sangat terlihat jelas melalui gaya penulisan teks tersebut, dengan mempertanyakan nasibnya untuk dapat tetap hidup dalam situasi dan kondisi yang dijalaninya. Di sisi lain, penjelasan dalam gaya teks membawa pemikiran-pemikiran manusia untuk tetap memperhitungkan segala sesuatu sekalipun dalam keadaan yang mendesak dengan tidak semata-mata menghalalkan segala cara. Contohnya untuk tidak rakus dalam segi apapun, terlebih lagi terkait harta, kerena penulis membawa pemikiran manusia untuk tetap berbagi kebaikan kepada manusia lainnya, terlebih lagi yang membutuhkan. Contohnya terlihat jelas dalam pembagian presentase hasil kerja walaupun dirinya sendiri sangat membutuhkan hak berkehidupan. Luapan emosi juga jelas pada kalimat deg-degan jadi seniman, yang mana menjelaskan ketidakpercayaan terhadap kurangnya penghasilan dari profesi yang telah ditekuninya, membuat dirinya cemas dalam menjalankan kehidupan di hari-hari berikutnya.

Bait 8; Lampu kota berpendar pelan. Kurasa sinarnya mulai mengancam, gelombang pertanyaan mulai datang. Mau kemana? Dari mana? Daftar dimana? Umur berapa? Ini Jakarta, hei kamu mau apa?

Pemaknaan denotasi dalam bait tersebut ada kata berpendar, yang mengartikan bercahaya seperti kelemayar, berputar, berpusing dalam kalimat pertama mengartikan lampu yang berada di salah satu perkotaan memancarkan sinarnya yang kelemayar. Kata selanjutnya sinar yang diartikan pancaran terang atau cahaya (kelip) mata (sangat tajam pada ketika marah). Selanjutnya kata mengancam, berarti menyatakan maksud (niat, rencana) untuk melakukan sesuatu yang merugikan, menyulitkan, menyusahkan atau mencelakakan pihak lain. Dalam kalimat tersebut menyatakan tanggapan hati terhadap cahaya yang mulai mengancam. Selanjutnya kata gelombang diartikan kelompok atau golongan yang bergerak maju beruntun-untun atau gerakan (pemogokan) yang beruntunruntun datang untuk menanyakan suatu hal. Mau kemana? Dari mana? Daftar dimana? Umur berapa? Ini Jakarta, Hei kamu mau apa? Kalimat tersebut adalah pertanyaan dari gelombang yang dimaksud, dengan menekankan pernyataan pada kata Ini Jakarta.

Sedangkan makna konotasi dalam bait tersebut pada kalimat lampu kota berpendar pelan mempunyai makna alat yang sejatinya dapat menerangi kota dengan cahayanya seolah mulai redup. Dan kalimat sinarnya mulai mengancam, kata sinar bermakna cahaya yang menyatakan kejernihan. Kata sinar disandingkan dengan kalimat mulai mengancam bermakna sorotan mata ketika sedang marah dan dipenuhi dengan ancaman. Gelombang suatu kelompok yang memiliki gerakan beruntun dengan cara mengancam dan memiliki sorotan mata yang tajam. Lebih lanjut dalam pemaknaan kalimat berikutnya, kelompok tersebut tidak membenahi cahaya yang mulai redup, melainkan semakin membuat redup atau membuat suatu ancaman dengan cara menyidak banyak orang. Cara yang digunakan untuk menyidak dengan menggunakan pertanyaan yang tak seharusnya ditanyakan. Mau kemana? Dari mana? Daftar dimana? Umur berapa? Ini Jakarta, Hei kamu mau apa? Dengan padanan kata Ini Jakarta menunjukkan kejadian tersebut dialami oleh Ibukota Negara Indonesia, Jakarta.

Selanjutnya, bait 9: Aku ingin mandi bir, kepalaku pusing, Aku ingin mandi bir, kepalaku pusing, Aku khawatir sebentar lagi anakku lahir.

Makna denotasi dalam kalimat pertama terdapat pada kata mandi yang berarti membersihkan tubuh dengan cara menyiramkan cairan, merendam diri dalam air atau dipenuhi dan kata bir adalah minuman yang mengandung alkohol yang dibuat dengan peragian lambat, maka kalimat Aku ingin mandi bir mengartikan keinginan untuk membersihkan tubuh dengan cara menyiramkan cairan minuman beralkohol. Kepala mengartikan otak dan kata pusing 
mengartikan sakit kepala, Aku khawatir sebentar lagi anakku lahir adalah kata yang diulang dalam bait sebelumnya, yaitu pernyataan seorang Jason Ranti terhadap anaknya yang akan lahir.

Makna konotasi dalam bait ini adalah lanjutan bait sebelumnya $A k u$ dalam kalimat ingin mandi bir Kepalaku pusing bermakna sebagai kesakitan pikiran yan dialaminya dalam bait sebelumnya sudah menjelaskan beberap faktor yang mendorongnya pada situasi tersebut, di antaranya ekonomi, politik, diskriminasi agama dan lainnya. Pada kata bir Jason Ranti tidak menegaskan dalam meminumnya karena itu adalah sebuah perumpaan, bahwa dirinya tidak meminum pun merasakan pusing yang sangat dalam dengan pengulangan dua kali kalimat tersebut, karena sebenarnya makna bir adalah benda yang dikonsumsi dengan cara diminum agar mendapatkan efek mabuk atau pusing. Pada kalimat aku khawatir sebentar lagi anakku lahir, adalah kalimat yang dirasa cukup tegas untuk mengetahui alasan kepusingan Jason Ranti, yaitu mempertimbangkan nasib anaknya yang akan lahir ditengah situasi yang dilaluinya.

Bait 10: 7-Eleven terlalu terang, Jelas Circle $K$ bukan pilihan, Ada sesuatu yang ingin kulanggar, Entah peraturan, entah ketetapan. $A h$, persetan dengan keadaan, Kucuri kesempatan dalam kesempitan, Semoga halal, kuyakin halal, Aku tak perlu fatwa mereka. Mana yang suci, mana yang dosa? Hei, ini jauh lebih nyata. Aku khawatir sebentar lagi anakku lahir

Makna denotasi dalam bait berikutnya terdapat dalam kata 7-eleven adalah nama suatu toko kelontong atau minimarket, demikian halnya kata Circle $K$. Kalimat bukan pilihan mengartikan yang tidak terpilih. Kalimat berikutnya yaitu Ada sesuatu yang ingin kulanggar, kata ingin mengartikan hendak, kata kulanggar berarti menyalahi atau melawan, makna dalam kalimat tersebut yaitu kehendak seseorang yang ingin melakukan kehendak untuk melanggar suatu hal. Entah peraturan, entah ketetapan, kata peraturan mengartikan tatanan, petunjuk atau kaidah, lalu kata ketetapan berarti keputusan. Ah, persetan dengan keadaan kucuri kesempatan dalam kesempitan, kata persetan mengartikan kata seru untuk menyatakan tidak mau tahu lagi, masa bodoh, tidak peduli. Lalu kata kucuri mengartikan ambil milik orang lain dengan diam-diam, kata kesempatan mengartikan waktu atau peluang, kata kesempitan berarti terdesak, kepicikan, kekurangan (uang, waktu dan sebagainya). Pada kalimat Semoga halal, kuyakin halal Aku tak perlu fatwa mereka Mana yang suci, mana yang dosa,? Kata halal mengartikan yang diperbolehkan atau diperbuat dengan sah. Kata fatwa yang berarti jawaban keputusan, pendapat yang diberikan oleh mufti tentang suatu masalah, lalu kata suci yang berarti bersih atau bebas dari dosa, dosa mengartikan perbuatan yang melanggar hukum Tuhan atau agama. Pada kalimat terakhir yaitu hei, ini jauh lebih nyata, aku khawatir sebentar lagi anakku lahir, kata jauh mengartikan sangat kurang, nyata mengartikan terbukti, dalam kalimat tersebut pernyataan terhadap pembuktian yang sangatlah kurang, untuk menghadapi kelahiran seorang anak.

Secara konotasi kalimat 7-Eleven terlalu terang, jelas Circle $K$ bukan pilihan bermakna bahwa toko 7-Eleven terlalu mewah atau bersinar dan Circle $K$ bukanlah toko yang baik untuk membeli konsumtif sehari-hari. Lalu pada kalimat selanjutnya Entah peraturan, entah ketetapan, ah, persetan dengan keadaan bermakna kehendak seseorang yang ingin menyalahi suatu peraturan dan ketetapan lantaran terdesak dengan keadaan, semisal dengan mengambil hak orang lain dalam keadaan yang mendesak. Pada kalimat aku tak perlu fatwa mereka, Mana yang suci, mana yang dosa? Bermakna suatu pertanyaan yang menyatakan bahwa saat seseorang mengambil hak orang lainnya, manusia tidak akan pernah mempertimbangkan dari beberapa pihak, terlebih untuk meninjau kesucian dan dosa yang didapat dari hal tersebut, semua cara dihalalkan demi menunjang kebutuhan semata. Penegasan hal tersebut terdapat dalam teks Semoga halal, kuyakin halal, pernyataan seorang yang mengikuti hawa nafsu tidak jauh akan menghalalkan berbagai macam cara. Lalu kalimat selanjutnya masih terkait seorang yang menunggu akan kelahiran anaknya dalam waktu dekat.

Bait 13; Masalah agama, masalah Si Kafir, Lagi-lagi dia, dia-dia lagi. Tuhan dipaksa turun ke jalan. Seisi surga berpegangan tangan.

Secara denotasi, dalam bait ini kata masalah mengartikan sesuatu yang harus dipecahkan, soal atau persoalan, agama berarti ajaran, sistem yang mengatur tata keimanan (kepercayaan) dan peribadatan kepada Tuhan Yang Maha Kuasa serta tata kaidah yang berhubungan dengan pergaulan manusia dan manusia serta manusia dengan lingkungannya. Kata kafir mengartikan orang yang tidak percaya kepada Allah SWT dan Rasulnya. Lagilagi dia, dia-dia lagi kalimat yang menunjukan kepada seseorang, atau kelompok yang melakukan hal yang sama. Tuhan dipaksa turun 
ke jalan kata Tuhan mengartikan sesuatu yang diyakini, dipuja dan disembah oleh manusia sebagai Yang Maha Kuasa, Maha Perkasa dan sebagainya. Paksa mengartikan sesuatu yang diharuskan walaupun tidak mau. Kata turun artinya bergerak ke arah bawah, kata jalan mengartikan tempat untuk lalu lintas orang. Seisi surga berpegangan tangan, kata isi mengartikan seluruh penghuni, kata surga mengartikan alam akhirat yang membahagiakan ruh manusia yang hendak tinggal di dalamnya (dalam keabadian), berpegangan tangan mengartikan bantu membantu atau bekerja sama.

Secara konotasi bait Masalah agama, masalah Si Kafir, kalimat tersebut bermakna penyudutan kepada seseorang yang tak seragam dalam meyakini suatu agama dan disebut sebagai kafir oleh mayoritas. Lagi-lagi dia, diadia lagi penyudutan kepada suatu pihak yang melakukan hal berulang-ulang. Tuhan dipaksa turun ke jalan penjelasan problematika setiap masalah yang dibungkus oleh agama, dengan membawa atas nama Tuhan untuk berdemo atau turun ke jalan. Seisi surga berpegangan tangan, menjelaskan bahwa penghuni surga saling bahumembahu untuk memaksa tuhan agar turun ke jalan, penghuni surga adalah orang-orang yang mempunyai amal kebaikan yang tinggi, saleh serta salehah.

\section{Makna Mitos}

Mitos yang ada dalam bait pertama tersebut adalah tentang hak kebebasan beragama yang meliputi hak kebebasan berpikir, dalam sesi wawancara kepada Jason Ranti ia memaparkan saat istriya sedang hamil, iya melihat tulisan ganyang Cina di tembok Kota, ia merasakan kecemasan karena istrinya keturunan cina. Selain itu Jason Ranti mengakui bahwa Ia besar dalam sebuah keluarga Katolik, Di tengah situasi dan kondisi seperti itu kelompok agama minoritas dalam suatu negara merasakan kecemasan terkait toleransi beragama, Indonesia mempunyai banyak agama di dalamnya, tetapi Indonesia tercatat sebagai negara dengan masyarakat mayoritas beragama Islam. Anjuran untuk menghargai perbedaan beragama tanpa keterpaksaan sudah jelas diterangkan oleh Al-Qur'an. "Tidak ada paksaan untuk (memeluk) agama (Islam); sesungguhnya telah jelas jalan yang benar dari pada jalan yang salah. Karena itu barangsiapa yang ingkar kepada Thaghut dan beriman kepada Allah Swt, maka sesungguhnya ia telah berpegang kepada buhul tali yang amat kuat yang tidak akan putus. Dan Allah Maha Mendengar lagi Maha mengetahui." (QS. Albaqarah:256).

Lanjut analisis mitos pada bait ketiga tersudut kepada seorang manusia yang mempunyai keyakinan berbeda dan merasa terancam dalam menjalankan hidupnya, tak ada ketenangan pikiran sedikit pun dalam keadaan yang dijalaninya, melalui peristiwa-peristiwa yang sangat menghebohkan terkait agama. Jason Ranti mengatakan bahwa toleransi itu menyebalkan, karena itu wacana mayoritas, selama ini kan selalu begitu misal kata seperti, heh, minoritas harus tahu diri," yang kerap sekali didengar oleh Jason Ranti. Karena mayoritas umat beragama di Indonesia adalah muslim maka dari bait ini bisa disimpulkan bahwa pemaknaan mitos di dalamnya erat sekali terkait polemik toleransi beragama dimana sudut pandang umat Non-Islam saat rentetan peristiwa beberapa waktu lalu, khususnya sebelum berlangsungnya pemilihan presiden sangat berlawanan arah, dari mulai pandangan terhadap umat muslim yang seharusnya rahmatan lil alamin tetapi justru terbalik, Kalimat takbir pun dianggap menyeramkan bagi mereka (minoritas) dan mencekam serta seolaholah untuk berpikir dan bernafas pun bagi kaum minoritas sangatlah sulit. Pandangan tersebut sangatlah berlawanan dengan konsep ajaran agama Islam yang megajarkan untuk saling melindungi antar sesama umat manusia. "Hai orang-orang yang beriman, janganlah kamu memasuki rumah yang bukan rumahmu sebelum minta izin dan memberi salam kepada penghuninya yang demikian itu lebih baik bagimu, agar kamu (selalu) ingat.." (QS. AnNur; 27). Secara garis besar perlindungan sesama umat manusia untuk mendapatkan perlindungan keamanan sangatlah jelas diajarkan oleh agama Islam, selain dalam perlindungan keamanan, Islam pun sangatlah mengajarkan konsep kebebasan dalam beragama tanpa unsur paksaan, "Tidak ada paksaan untuk (memeluk) agama (Islam); sesungguhnya telah jelas jalan yang benar dari pada jalan yang salah. Karena itu barangsiapa yang ingkar kepada Thaghut dan beriman kepada Allah Swt, maka sesungguhnya ia telah berpegang kepada buhul tali yang amat kuat yang tidak akan putus. Dan Allah Maha Mendengar lagi Maha mengetahui." (QS. Albaqarah: 256). Maka dari itu Islam sangatlah menjunjung kedamaian dan persatuan di dalamnya tanpa perlu ada unsur paksaan, terlebih hal tersebut termasuk ke dalam ajaran untuk memperkuat toleransi dalam beragama. 
Mitos selanjutnya bait kelima. Dalam bait ini mempunyai mitos dalam kalimat 30 persen dipotong teman, 20 persen untuk minuman, yang tersisa kubawa pulang, Tapi kurasa ini masih kurang yang menjelaskan terkait pesan saling berbagi dan menghargai hasil kerja orang lain serta memikirkan kehidupan keluarga di rumah, walau pun ia merasa penghasilan yang di dapat tidak mencukupi untuk kesehariannya. Di sisi yang lain pesan yang terlihat terkait khodrat manusia yang tidak akan pernah merasa puas dalam segi apa pun selalu merasa kekurangan. Dalam konsep saling berbagi tersebutlah dapat memperkuat kebersamaan. Dalam konteks apa pun kebersamaan akan membawa kepada rasa persaudaraan yang kuat, bahkan justru kebersamaan itu menjadi "kekuatan" manusia untuk melakukan apapun. Sebagai mahluk yang saling membutuhkan satu dengan yang lain. "Allah SWT menciptakan manusia dari jenis laki-laki dan perempuan dan bersuku-suku dan berbangsa-bangsa tidak lain untuk saling mengenal." Selain itu konsep untuk tidak rakus dan serakah yang dijelaskan sangatlah erat kaitannya dengan meredam hawa nafsu. Allah berfirman dalam al-qu'ran yang bengatakan, "Hai Daud, sesungguhnya kami menjadikan kamu khalifah (penguasa) di muka bumi, maka berilah keputusan (perkara) di antara manusia yang adil dan janganlah kamu mengikuti hawa nafsu, karena ia akan menyesatkan kamu dari Allah. Sesungguhnya orang-orang yang sesat dari jalan Allah akan mendapat azab yang berat karena mereka melupakan hari perhitungan,", (QS. Shaad: 26). Dengan melihat ayat tersebut secara garis besar kesesatan memperturutkan hawa nafsu, selain itu meredam hawa nafsu dapat meredam permasalahan, konflik-konflik sosial yang ada, polemik yang menyangkut keberagamaan dan keberagamaan.

Selanjutnya bait ke delapan, mitos dalam bait ini sangatlah jelas sekali terkait kurangnya konsep toleransi beragama dan bernegara di dalamnya, manusia memang diperbolehkan dalam berserikat atau membuat kelompok, tetapi tidak melebihi norma yang berlaku atau menjadi arogan dan semena-mena kepada kelompok yang lebih kecil atau perorangan. Dengan cara menghargai perbedaan yang ada dan sikap saling menghormati mutllak diperlakukan, tidak menganggap kelompok yang lain lebih rendah, kesediaan mental untuk saling menerima segala perbedaan yang ada. Selain itu firman Allah SWT mengatakan bahwa, "Dan di antara tanda-tanda kekuasaannya ialah menciptakan langit dan bumi dan berlain-lainan bahasamu dan warna kulitmu. Sesungguhnya pada yang demikian itu benar-benar terdapat tanda-tanda bagi orangorang yang mengetahui," (QS. Ar-rum: 22). Ayat ini menunjukan bahwa perbedaan memang kehendak Tuhan, hanya saja perbedaan itu dalam rangka yang lebih baik. Islam mengajarkan persamaan di antara sesama manusia, dan oleh karena itu Islam juga sangat mengutuk perlakuan diskriminatif di antara manusia dan merasa dirinya lebih tinggi dari orang lain sehingga merendahkan martabat orang lain. Perbedaan warna kulit, bahasa, budaya jenis kelamin dan lain sebagainya bukan merupakan alasan manusia yang satu memiliki derajat yang tinggi di antara yang lainnya.

Dilanjutkan pada bait kesembilan, dimana mitos dalam bait ini mempunyai pesan dalam mempertanyakan hak berkehidupan bagi kelompok minoritas yang tentu saja meliputi mendapatkan rasa aman di suatu negara yang beragama. Islam sangatlah mengajarkan terkait memberikan rasa aman dan nyaman kepada umat manusia, Allah berfirman, "Hai orangorang yang beriman, janganlah kamu memasuki rumah yang bukan rumahmu sebelum minta izin dan memberi salam kepada penghuninya yang demikian itu lebih baik bagimu, agar kamu (selalu) ingat," (QS. An-Nur: 27). Secara garis besar Islam sangatlah mengajarkan untuk saling menjunjung rasa aman dalam menjalani kehidupan, karena jika hak keamanan untuk hidup sudah terpenuhi, maka dapat terciptanya kerukunan antar-umat.

Di bait 10, mitos yang terkandung adalah pesan Jason Ranti tentang manusia yang kalah melawan hawa nafsu diri sendiri terkait kesulitan dalam hidup. Ada beberapa faktor yang menjadikan manusia berpikir kesulitan dalam hidup. Di antaranya ekonomi, sosial, politik agama dan lain sebagainya. Dari sisi ekonomi, orang tersebut merasa ia selalu hidup ini tidak berarti karena untuk mencukupi kebutuhan hidupnya pun tidak bisa, Dalam hal ini kita sering melihat ada orang bunuh diri karena persoalan ekonomi, bahkan kita juga mendengar ada seorang ibu bersama anaknya meninggal karena kelaparan, Belum lagi berbagai kasus kriminal yang mengorbankan nyawa hanya karena uang beberapa ribu saja. Pendek kata himpitan ekonomi sering menjadikan orang sulit untuk menjalani hidup, padahal sebenarnya persoalan ekonomi bukanlah segalanya dalam hidup, yang terpenting ketenangan dan kedamaian hati. Dalam sosial, orang yang hidup merasa sulit bisa jadi karena ia tidak diterima lingkungannya, sehingga ia harus menjadi hidupnya dengan tidak menentu. Dari sisi 
politik bisa jadi karena karir politiknya sudah habis, tidak terpilih kembali. Dari sisi agama, orang yang merasa kesulitan tersebut merasa bahwa agama yang dianutnya dikatakan sebagai aliran terlarang sehingga harus dibubarkan. Maka dari itu pengelolaan diri sendiri dari hawa nafsu yang terus masuk ke dalam jiwa manusia perlu dilawan agar terciptanya kedamaian di setiap lapisan kehidupan manusia terkait kerukunan hidup.

Pada bait 13 Jason Ranti mengeluarkan sikap kritisnya dalam menghadapi permasalahan keagamaan yang dialaminya. Jason Ranti menentang penyudutan kata kafir untuk kaum minoritas dan penyudutan setiap masalah yang terjadi seolah-olah dikarenakan oleh kaum atau kelompok yang berbeda agama. Di sisi lain Jason Ranti juga mengkritik pedas orang-orang yang kerap kali berdemo selama rentetan peristiwa 2014-2019 dengan membawa atas nama Tuhan. Dalam bait tersebut jelas bahwa Indonesia kekurangan sikap dan konsep menghargai sesama manusia terlebih lagi pada masalah keyakinan. Terkait penyudutan suatu agama oleh agama lain dijelaskan dalam AlQur'an, "Maka hadapkanlah wajahmu dengan lurus kepada agama (Allah), (tetaplah atas) fitrah Allah yang telah menciptakan manusia menurut fitrah itu. Tidak ada perubahan fitrah Allah. (itulah) agama yang lurus; tetapi kebanyakan manusia tidak mengetahuinya," (QS. Ar-rum: 30). Dilanjutkan ayat berikutnya, "Dengan kembali bertaubat kepadanya dan bertaqwalah kepdanya serta dirikanlah shalat dan janganlah kamu termasuk orang-orang yang mempersekutukan Allah. (QS. Ar-rum: 31). Ayat tersebut secara jelas mengemukakan bahwa agama sudah menjadi fitrah manusia. Manusia tidak bisa di lepaskan dari agama "tauhid". Bahkan sejak sebelum dilahirkan, manusia sudah berjanji tentang ketauhidannya kepada Allah SWT. Maka dari itu permasalahan agama sudah digariskan oleh Allah SWT saat manusia hadir di bumi, perkara ketidak selarasan manusia dalam mempunyai keyakinan, tidak lah perlu dibatasi atau disudutkan. Karena Allah SWT sudah jelas memberi petunjuk mana yang benar dan mana yang salah.

\section{KESIMPULAN}

Lagu Dua Ratus Dua Belas karya Jason Ranti lahir dari beberapa hal. Berdasarkan makna pesan toleransi beragama secara denotasi di dalam empat belas bait lagu tersebut, ada tujuh bait yang berkenaan dengan pesan toleransi beragama yaitu bait ke satu, tiga, lima, delapan, sembilan, sepuluh dan tiga belas. Dari ketujuh bait tersebut secara denotasi memberikan pesan bahwa kelompok beragama minoritas sering disudutkan oleh kelompok beragama mayoritas dan seolah-olah kata kafir adalah sumber masalah di negara Indonesia. Serta berdasarkan makna konotasi dalam lirik lagu tersebut setelah dianalisis bahwa ada tujuh bait yang mendominasi pesan toleransi beragama di dalamnya. Bait tersebut memaparkan bahwa kehidupan umat minoritas beragama sangatlah dipandang sebagai pembawa masalah pada polemik besar pada medio 2014-2019 di negara Indonesia, sehingga sikap intoleran lebih mendominasi ketimbang toleransi yang ada.

Pada lagu Dua Ratus Dua Belas Karya Jason Ranti mitos di dalamnya yaitu suatu pesan yang menyatakan bahwa toleransi beragama adalah ajaran kebaikan yang perlu dimiliki oleh seluruh umat manusia yang memeluk agama. Sementara intoleransi tidak diperkenankan oleh seluruh pemeluk agama. Sikap toleransi harus tetap dijaga pengimplementasiannya sebagai upaya menjaga persatuan di atas keberagaman.

\section{DAFTAR PUSTAKA}

Abdullah, Amin, M. 2015, Studi Agama: Normativitas Atau Historitas, Yogyakarta: Pustaka Pelajar

Abdullah, Masykuri, 2001, Pluralisme Agama dan Kerukunan Dalam Keragaman, Jakarta: Penerbit Buku Kompas.

Agustinus Shindu Alpito, 2017, Jalan Pikir Jason Ranti https://www.medcom.id/hiburan/indis/GK dg8Rmk-jalan-pikir-jason-ranti, Medcom.id diakses 13 November 2019.

Ajeng Quamila, Cap Gorilla, Ganja Sintetis yang Bikin Pemakainya Hidup Seperi Zombie,

https://www.google.com/amp/s/hellosehat. com/hidup-sehat/tips-sehat/efek-bahayacap-gorilla-ganja-sintetis/\%3famp, hellosehat.com diakses pada, selasa 09 Juni 2020, pukul 13:00 WIB

Alam Zhu L Anto,2016, Amuk Massa Di TanjungBalai, Vihara dan Kelenteng Dibakar,https://www.bbc.com/indonesia/b erita_indonesia/2016/07/160730_indonesia _rusuh_tanjung_balai, bbc.com, diakses pada 13 Juni 2020

Alniezar, Faiz, 2015, Jangan Membonsai Ajaran Islam, Jakarta: Omah Aksoro, 
Badan Pengembangan Bahasa dan Perbukuan, Kementerian Pendidikan dan Kebudayaan Republik Indonesia, 2016-2019 KamusBesar Bahasa Indonesia (KBBI), kamus versi offline/luring (luar jaringan)

Bagaskara Isdiansyah, 2 Februari 2019, Pandangan'Nyeleneh'Musisi Jason Ranti Soal Polemik RUU Permusikan, https://www.pantau.com/berita/pandangannyeleneh-musisi-jason-ranti-soal polemikruu-permusikan, Pantau.com diakses (Kamis 14 November 2019) Pukul 13.26 WIB

Barthes, Roland. 2010, Imaji, Musik, Teks: Analisis Semiologi atas Fotografi, Iklan, Film, Musik, Alkitab, Penulisan dan Pembacaan serta Kritik Sastra, Yogyakarta: Jalasutra

Boisard, A, Marcel, 1980, Humanisme Dalam Islam, Jakarta: Bulan Bintang

Danesi, Marcel. 2004, Pesan, Tanda dan Makna: Buku Teks Dasar MengenaiSemiotika dan Teori Komunikasi, Yogyakarta: Jalasutra.

Desyandri. 2012, Pendidikan Seni Musik Humanis: Suatu tinjauan konseptual, Padang: Universitas Negeri Padang

Dyah Paramita Saraswati, 11 Oktober 2017, Jason Ranti dan Lirik-lirik Liar di 'Akibat Pergaulan Blues', https://m.detik.com/hot/main-stage/d3679449/jason-ranti-dan-lirik-lirik-liar-diakibat-pergaulan-blues , Detik.com, diakses Kamis 14 November 2019, Pukul 13:00 WIB.

FKUB, 2008, Kapita Selekta Kerukunan Umat Beragama, Semarang: Forum Kerukunan Umat Beragama (FKUB)

Gilarnic G David.,1959, Webster's Wold Dictionary of America Language. New York: The World Publishing Compan

Jamaruddin, Ade. 2016, Jurnal Membangun Keberagamaan Dalam Perspektif AlQur'an, Riau: UIN Sultan Syarif Kasim Riau

Jason Ranti, Musisi, 23 April 2020, Wawancara via Dalam Jaringan (Daring)

Jirhanuddin, 2010, Perbandingan Agama: Pengantar Studi Memahami AgamaAgama, Yogyakarta: Pustaka Pelajar

John, Little, W, Stephen. 2018, Teori Komunikasi, Jakarta: Salemba Humanika

Kapanlagi.com, Lirik lagu Dua Ratus Dua Belas https://m.kapanlagi.com/lirik/artis/jasonranti/dua-ratus-dua-belas-hadiah/, diakses pada 31 Juni 2020 pukul 13.00
Kementerian Pendidikan dan Kebudayaan, 2015, Pendidikan Agama Kristen dan Budi Pekerti Pusat Kurikulum dan Perbukuan, Balitbang, Kemdikbud

Kriyantono, Rachmat. 2007, Teknik Praktis Riset Komunikasi, Jakarta: Kencana

Kustin Ayuwuragil D, 7-eleven Profil, https://m.merdeka.com/7-eleven/profil, merdeka.com, diakses pada 10 juni 2020, pukul 14.00 WIB

Majid, Cholis, Nur. dkk, 2010, Passing Over Melintas Batas Agama, Jakarta: PT. Gramedia Pustaka Utama

Medcom.id, 13 Februari 2018, Masjid Di Tuban Diserang Orang Tidak Dikenal, https://www.google.com/amp/s/m.medcom .id/amp/GNGMnwAk-masjid-di-tubandiserang-orang-tak-dikenal, diakses pada Rabu 12 Februari 2020

Mohammad Saifulloh, 28 april 2015, "Radikalisme Atas Nama Agama Jadi Ancaman Bersama, "https://www.google.com/amp/s/nasional. okezone.com/amp/2015/04/28/337/114118 7//radikalisme-atas-nama-agama-jadiancaman-bersama, okezone.com, diakses pada 13 Juni 2020

Morissan,

2015, TeoriKomunikasiIndividuHingga Massa, Jakarta: Prenada Media

Muhammad Rushdi, 1Oktober 2017, Wawancara Eksklusif bersama Jason Ranti, https://www.medium.com/wawancaraeksklusif-bersama-jasonRanti6b428bcf79fb, Medium.com, diakses Rabu 13 November 2019, Pukul 22:00 WIB.

Mujani, Saiful, 2007, Muslim Demokrat: Islam, Budaya Demokrasi dan Partisipasi Politik di Indonesia Pasca-Orde Baru, Jakarta: Gramedia Pustaka Utama

Nazaruddin Kahfie, 2015, Pengantar Semiotika, Yogyakarta: Graha Ilmu

Natalia Bulan R P, Profil Jason Ranti, 18 agustus 2019 https//www.google.com/amp/s/video.tribu nnews.com/amp/view/91826/profil-jasonranti-aktor-dan-musisi, (tribunnews.com: 18 Agustus 2019) diakses pada Selasa 19 Mei 2020, Pukul 13:00 WIB.

Poerdarminta, W,J,S. 2005, Kamus Besar Bahasa Indonesia, Jakarta : BalaiPustaka

Pmg/pmg, 27 agustus 2019 PGI :Pembubaran Ibadah di Gereja Indragiri Hilir Melukai Umat, https://m.cnnindonesia.com/nasional/2019 
0827111757-20424937/pgi-pembubaranibadah-di-gerejaindagiri-hilir-melukaiumat, cnnindonesia.com, diakses pada 13 Juni 2020

Seto, Indiwan. 2013, Semiotika Komunikasi: Aplikasi Praktis Bagi Penelitian dan Skripsi Komunikasi, Jakarta: Mitra Wacana Media.

Shadily Hassan dan Echols M John, 2007, Kamus Inggris Indonesia, Jakarta: PT. Gramedia

Shelbi Asrianti, 10 September 2018, Dialog Kritis dalam Musik Jason Ranti https://www.google.com/amp/s/m.republik a.co.id/amp/petbd8349 Republika, diakses Kamis 14 November 2019

Sholehuddin. 2018, Damai Beragama, Damai Bernegara Tangerang Selatan: Mutiara Barokah Multigrafika

Shuker, Roy. 2020, Key Concept in popular music, Pschycology Press Lubis Yusuf Kahyar, 2006, Dekonstruksi Epistimologi Modern, Jakarta: Pustaka Indonesia Satu
Sobur, Alex. 2013, Semiotika Komunikasi, Bandung: PT Remaja RodaKarya.

Sobur, Alex. 2009, Analisis Teks Media, Suatu Pengantar Untuk AnalisisWacana, Analisis Semiotik, dan Analisis Framing, Bandung: PT Remaja Rosdakarya

Tim Penyusun Terjemahan Susi, 2006, Kitab Susi Solo: Matakin

Tryning Rahayu Setya W, Circle K Profil, https://m.merdeka.com/circle-k/profil/, merdeka.com, diakses pada 10 juni 2020, pukul 14.00 WIB

Umar Hasyim, 1979, Toleransi dan Kemerdekaan Beragama dalam Islam Sebagai Dasar Menuju Dialog dan Kerukunan Antar Umat Beragama, Surabaya: Bina Ilmu,

Vera, Nawiroh, 2014, Semiotika Dalam Riset Komunikasi, Indonesia: Ghalia

Warson Munawir Ahmad, 1997, Kamus Arab Indonesia Al-munawwir, Surabaya: Balai Pustaka Progresif 